\title{
BİR MİMAR SİNAN ESERİ KAPI AĞASI HADIM MAHMÛD AĞA CAMİNIN HICRİ 1020 (M.1611) YILINA AİT VAKIF DEFTERİ
}

\author{
РУКОПИСЬ ОБ ИМУЩЕСТВЕ МЕЧЕТИ МАХМУДА АГА, ДАТИРОВАННОЙ \\ ХИДЖРЫ (1020/ М.1611) И ОПИСАННОЙ В ПРОИЗВЕДЕНИИ \\ «ДЕРЕВЯННАЯ ДВЕРЬ» МИМАРА СИНАНА
}
FOUNDATION BOOK OF THE HIJRI 1020 OF CHIEF WHITE EUNUCH MAHMÛD AĞA MOSQUE, A WORK OF MIMAR SINAN (1611 A.D.) ${ }^{1}$

Ahmet UYANIKER*

\section{ÖZ}

Osmanlı Devleti'nin altı yüz yılı aşan ömrü içersinde, vakıf sisteminin Türk toplumunda sosyal ve milli dayanışmayı sağlamada oynadığı rol ve icrâ ettiği fonksiyon oldukça önemlidir. Çünkü Osmanlı yerleşim yerlerinin bayındırlık, eğitim-kültür, sağlık ve sosyal yardım hizmetleri büyük ölçüde vakıflar tarafından karşılanıyordu. Bu bağlamda Osmanlı şehirlerinin hemen hemen hepsinde Osmanlı Devlet adamları ve hayırsever halk tarafından yaptırılan vakıf eserlere rastlamak mümkündür. Osmanlı şehirleri içersinde İstanbul uzun yıllar Devlete başkentlik yaptığı için tarihi pek çok askeri, sivil ve dini eseri barındırmaktadır.

$\mathrm{Bu}$ eserlerden bir kısmı uzun yıllara direnerek günümüze ulaşmıştır. Bu yapılar tarihi, mimari ve kültürel yönleriyle farklı çalışmalara konu oluşturmaktadır. İstanbul'da Osmanlı Devletinden günümüze ulaşabilmiş tarihi yapılardan birisi Mahmûd Ağa Cami'dir. Eser Kanuni Sultan Süleyman'ın bâbüssaade ağası Mahmûd Ağa tarafından yaptırılmıştır ve Mimar Sinan'ın yapıtları arasında anılmaktadır. Cami halen İstanbul Sütlüce Mahallesi Damar Sokak da ibadete açıktır.

Cami Mimar Sinan'ın İstanbul'daki diğer yapıtlarına kıyasla sönük kaldığı için çok fazla tanınmamakta ve hakkında fazla belge ve bilgi bulunmamaktadır. Bu çalışmada Mahmûd Ağa Cami'nin Hicri 1020 (Miladi 1611) yılına ait vakıf defterinde bulunan veriler ve mevcut bilgilerle Mimar Sinan'ın az bilinen bu yapıtı ve caminin vakıf kurucusu hakkında bilgi verilmiştir. Zira Başbakanlık Osmanlı arşivi belge taramasında cami ve yaptıranı hakkında incelenilen defterden başka vakıf defterine rastlanmamıştır. İlerleyen zamanda yeni belgelerin ortaya çıkması konuya katkı sağlayacaktır.

Anahtar Kelimeler: Mimar Sinan, Cami, Bâbüssaâde, Mahmud Ağa Cami, Vakıf.

\section{АННОТАЦИЯ}

На протяжении более правления Османской империи, система религиозных фондов играла роль в укреплении функции социальной основы и обеспечении национальной солидарности в турецком обществе. Так как в местах расселения

\footnotetext{
${ }^{1}$ DOI : $10.17498 /$ kdeniz.489

* Ardahan Üniversitesi, İİB, Uluslararası İlişkiler Bölümü, öğretim üyesi, ahmetuyaniker@ardahan.edu.tr
} 
Османов развитие образования и культуры, здравоохранения и социального обеспечения поддерживалось в основном за счет фондов. Поэтому в всех городах Османов встречаются рукописи о благотворительности людей и общественной деятельности Османской империи. Среди городов Османской империи Стамбул как историческая столица вбирала большое количество военных, гражданских и религиозных записей.

Часть этих записей сохранилась и до наших дней. Они заложили начало истории, архитектуры и культуры. Среди исторических строений является мечеть Махмуда Ага в Стамбуле, сохранившаяся до сегодняшнего дня. Это произведение создано при поддержке Махмуда Агъа, дяди Султана Сулеймана и входит в один ряд творений Мимара Синана. Мечеть до сих пор функционирует в районе Сютлюдже Махаллеси на улице Дамак в Стамбуле. Эта мечеть является одной из обычных работ Мимар Синана, по сравнению с другими его произведениями в Стамбуле, поэтому нет никакой информации в документах. В данной работе исследуются рукописи, содержащие данные о строительстве и деятельности мечети мечети Махмуда Ага, датированной Хиджры (1020/ м.1611) и описанной в произведении «Деревянная Дверь» Мимара Синана.

Данные были также взяты из Государственного архива Османской империи и из других фондов. Возникшие вопросы войдут в материалы новой книги.

Ключевые слова: Мимар Синан, Мечеть, Bâbüssaâde, Мечеть Махмуд Ага, Фонд.

\section{ABSTRACT}

The system of foundation plays an important role and a function in ensuring social and national solidarity in Turkish society in the lifetime of more than six hundred years of the Ottoman Empire. Since public works, education and culture, health and welfare services of the Ottoman settlements were met largely by foundations. In this context, in almost all cities of the Ottoman Empire the works of the foundations that were built by Ottoman statesmen and benevolent citizens can be found. Among the cities of Ottoman, Istanbul has several military, civil and religious works as it was the capital of the State for many years

A portion of these works have survived resisting for many years. These structures are subjected to different studies from historical, architectural and cultural aspects. One of the historic structures that has survived from the Ottoman Empire in Istanbul is Mahmud Ağa Mosque. The work was built by Suleiman the Magnificent's Babüssaade, Mahmûd Ağa, it is also referred to as a work of Architect Sinan. The mosque is still open to worship in Sutluce District- Damar Street in Istanbul.

The mosque is not much known as paled in comparison with other works of Architect Sinan in Istanbul, and there is not much information and document about it. In this study, it was aimed to give an information about this less known work of Architect Sinan and the founder of the mosque's foundation with the existing knowledge and the data contained in the book belonging to the year Hijri 1020 (1611 A.D.) of Mahmud Ağa Mosque. Since, there has been no other foundation books than the examined one found about the mosque and its builder in the document scanning of Ottoman Archives in Prime Ministry. The emergence of new documents in the following years will contribute to the subject.

Keywords: Architect Sinan, Mosque, Babüssaade, Mahmoud Ağa Mosque, Foundation. 


\section{GíRiş}

Vakıf, insanlarla beraber mevcut olan karşılıklı dayanışma ve başkalarına iyilik yapma duygusunu, hukuki statüye kavuşturan ve ona süreklilik kavramını sağlayan, tüzel kişiliğe sahip hukuki ve sosyal bir müessesedir (Akbulut,2007:64)

Vakıf; terim olarak, bir malı alınıp satılmaktan ebedî olarak alıkoymak, kişi mülkiyetinden çıkararak Allah yolunda hapsetmek ve menfaatini insanlar için tasadduk etmek demektir (Kaya, 2014:34). Vakıf, aynı zamanda vakıf akdinin mevzûunu teşkil eden menkul ve gayrimenkul malları da ifade etmektedir. Vakıf yapan kimseye vâkıf, vakfedilen şeye de mevkûf denir (Akbulut, 2007:65).

Vakıf müessesesi gücünü; karşılıklı yardımlaşma ve yoksulun gözetilmesini, sosyal hayat için zaruri kabul eden İslâm dininden alır. Bu açıdan bakıldığında vakıf, hem dinî, hem de sosyal bir müessesedir. Türk tarihindeki yerini esas aldığımız takdirde ise, vakfin tamamıyla millî bir müessese olduğunu görürüz. Çünkü vakıf, milli bünyenin gelişmesinde ve kuvvetlenmesinde mühim bir rol oynamıştır. Bu açıdan Osmanlı devri Türk vakıfları, yüzyıllar boyunca millet hayatında sosyal nizamın her türlü sarsıntıdan korunmasını sağladığı gibi, memleketin hayatî önemi pek büyük olan davalarına da geniş ölçüde hizmeti dokunmuştur (Ünal,1999:18). Başta padişah ve aile efrâdı olmak üzere devlet yöneticileri, askerler, âlimler ve halktan zengin olanlar, hayırlarını vakıflar kurarak gerçekleştirmişler ve ebediyen halka mal etmişlerdir (Akbulut, 2007:65). Bu nedenle vakıflar, Osmanlı'nın hemen hemen her döneminde padişahlar, hanedan üyeleri, sadrazamlar ve diğer devletve din adamları tarafindan desteklenmiştir (Bekçi ve Apalı, 2015:11).

Merkezi yönetim tarafından hukuksal çerçevesi belirlenerek ve denetlenen vakıflar vasıtasıyla bir çok kamusal hizmet, gönüllülük çerçevesinde bir ekonomik modelle çözülmüştür (Köprülü,1942:25). Böylece Osmanlı şehirlerinde çeşitli hizmetlerin yerine getirilmesinde büyük bir önem arz eden Vakıflar sayesinde genel olarak, şehrin bütününü ilgilendiren her türlü hizmet; cami, okul, kitaplık, hastane, han, çeşmeler, sebiller, imaretler, su getirme ve bu tesislerin bakımı, hatta bazen mezarlıklar ve bunlara benzer eserlerin ( Bayartan, 2008:158). \%99'u vakıf eselerdir. Bunları inşa ettiren ümerâ, ulemâ ve ticaret ve zenaat erbabı zenginler, arazi, dükkan ve benzeri gayri menkullerinin gelirlerini kendi adlarını taşıyan bu eserlere tahsis etmişlerdir (Ünal,1999:19). Osmanlı şehirlerinin gerek kuruluş ve gerekse gelişmesine büyük katkı sağlayan bu vakıflar, sosyal hayatın hemen hemen tamamına nüfuz etmiş, aynı zamanda şehirlerin siluetini ve mimarisini de oluşturmuştur ( Bayartan, 2008:158).

Diğer birçok müessesede olduğu gibi, vakıf müessesesinin kuruluşunda da Osmanlılar, tekâmül safhasını tamamlamış bulunan Selçuklu devri vakıflarını örnek aldılar. Osmanlı Devleti'nin altı yüz yılı aşan ömrü içersinde, vakıf sisteminin toplum hayatında oynadığı rol ve icrâ ettiği fonksiyon çok önemlidir. İmparatorluğun kuruluşundan, yirminci yüzyılda Türkiye Cumhuriyeti Devleti inkılâbına kadar, toplum hayatının her safhasında vakfın, vazgeçilmez bir unsur olduğu görülür (Ünal,1999:17).

Osmanlılarda 1826'da kurulan Evkaf Nezareti'nden önce vakıflar, vakıf kuran kişilerin (vâkıf) şartlarına göre idare ediliyor, bunlar ayrı nezaretlerce kontrol ediliyorlardı. Genel yönetimi vakfiyelerindeki şartlara göre değişen bu nezâretler şunlardır (Yediyıldız, 1986:163-164.)

1. Sadr-1 Âli Nezâreti: "Sadrazamların nezâretine şart edilmiş" olan vakıfların genel idaresi demektir. Fatih Sultan Mehmed'in vakıflarının nezaretini sadrazamlara vermesiyle 868/1464 tarihinde doğmuş, daha sonra sadrazamlara meşrut olan vakıfların çoğalmasıyla genişlemiştir. 
2. Şeyhülislâm Nezâreti: "Şeyhülislâmların nezâretine şart edilmiş" olan vakıfların genel idaresi demektir Sultan II. Bayezid'in İstanbul'da ve diğer yerlerde yaptırdığ hayır eserleri için kurduğu vakıfların nezâretini 912/1506 tarihinde Şeyhülislâm Alâeddin Ali Efendiye vermesiyle doğmuştur. $\mathrm{Bu}$ nezarete bütün ulema ve şeyhülislâm müntesipleri vakıflarının nezâretleri, şeyhülislâmlara şart edilerek genişlediğinden tezkireci efendiler tarafından idare edilirdi.

3. Bâbüssaâde (Kapı) Ağası Nezâreti: Harem-i hümayundaki kadınlar ve sultanlar ile kap1 ağaları ve mensuplarından vakıflarının nezâretini kapı ağalarına şart eden vakıfların genel idaresi demektir. Hürrem Sultan'ın 952/1545 tarihinde vakıfların nezaretini Kapı Ağası Hadım Mehmet Ağa'ya şart etmesiyle doğmuştur. Bu nezâret kapı halifeleri tarafından idare edilirdi.

4. Dârüssaâde Ağası (Haremeyn Evkâfi) Nezâreti: Bu nezâret Muharrem 995 /Aralık 1586 tarihinde kurulmuştur. Ancak 2 Recep 996/28 Mayıs 1588 tarihli bir belgeden anlaşıldığına göre Dârüssaâde ağalarına Haremeyn Evkâfı nezareti verilmiştir. Hâsılatının bir miktarı veya tamamı Haremeyn-i Şerifeyn halkına şart edilmiş olan vakıfların genel idaresi demektir.(Bayır, 2012:325).

1826 yılında "Evkaf-1 Hümayun Nezareti" vakıfların yönetimi için kurulmuştur. Cumhuriyetten sonrada ise de vakıfların yönetim ve denetimi, 1924 yılına kadar "Şeri'yye ve Evkaf Vekâleti'ne bırakılmıştır (Korkusuz,2008:83).

\section{OSMANLI DEVLETİ'NDE BÂBÜSSAÂDE (KAPI AĞASI) NEZÂRETİ}

Camiyi yaptıranın Kanuni Sultan Süleyman'ın bâbüssaâde ağası olması nedeniyle Osmanlı Devleti'nde Saray yönetimi içinde yer alan bu makam ile ilgili bilgi vermek yerinde olacaktır.

Osmanlı Devleti, merkezi ve mutlak devlet esaslarına göre teşkilatlanmıştı. Hükûmet (divan), ordu ve eyaletler, doğrudan doğruya padişahın şahsına bağlı bir bütün olarak düşünülmüştür. Bu sebeple saray, hem padişahın özel hayatının geçtiği evi, hemde devlet işlerinin yürütüldüğü esas merkez (büro) durumunda olup, devletin kalbi demekti. Devletin yürütme organı olan hükûmet, padişahın kapısında toplanıyordu. Osmanlı sarayı esas itibariyle padişahın husûsi hayatının geçtiği enderûn (iç saray) ve hükûmet işlerinin görüldüğü ve resmî hayatın geçtiği bîrûn (dış saray) olmak üzere iki kısımdan meydana gelir (Ünal,1997:18).

Osmanlılar'da Darüssaade tabiri Yaklaşık 380 yıl padişahların ve ailelerinin ikametgâhetı olan Topkapı Sarayı'nın Harem Dairesi için kullanılmıştır (Turan, 1999:129). 700 dönümlük bir arazi üzerine kurulan Topkapı sarayı ana hatlarıyla 3 kısımdan meydana gelir. Bâb-1 hümâyûn denilen ana kapı ile bâb's-selâm denilen ikinci kapı arasında Bîrûn'a dâhil ilk avlu bulunmaktadır. Bundan sonra Bâbüssaâde denilin üçüncü bir kapı daha vardır ki, bu iki kap1 arası da bîrûn'a dâhil olup alay meydanı denilmektedir. Bâbüssaâde kapısının hemen gerisinde Fatih Sultan Mehmed tarafından arz odası yaptırılmıştır. Padişah yabancı devlet adamlarını ve elçilerini burada kabul ederdi. Bâbüssaâde gerisinde arz odası'ndan başka, enderûn, harem-i hümâyûn ve hırka-i sa'aâdet dairesi vardır (Ünal,1997:20).

Bâbüssaâde kapısı padişahın resmi hayatının bitip resmî hayatının başladığı kapıdır. Tersi düşünülürse bâbü's-sa'âde, padişahın özel hayatının bitip resmî hayatının başladığı yerdir (Ünal,1997:20).

Padişahın özel dairesinin bulunduğu, hanımları, çocukları ve cariyelerinin yaşadığı bu yerin kendine has bir teşkilatı ve görevlileri vardı. Buranın her türlü hizmetiyle uğraşan ve 
Darüssaade ağaları denilen bu görevliler, padişaha ve ailesine yakınlıkları sebebiyle Osmanlı siyasi tarihinde önemli roller oynamışlardı (Turan, 1999:129).

Harem ağaları ile Enderun teşkilâtından Bâbüssaâde cemaatine mensup ağalar tavâşî (hadım) idi. Ortaçağ'da Müslüman ve Türk devletlerinde mevcut olan tavâşî veya hadım ağalar, Çelebi Sultan Mehmed zamanından itibaren Osmanlı sarayında da görevlendirildiler. Bunlar beyaz hadımlar (akağalar) ve zenci hadımlar (karaağalar) olmak üzere iki ayrı sınıftı. Akağalar, sarayın Enderun bölümünün başladığı yer olan ve Bâbüssaâde denilen kapısında görevli olduklarından kendilerine Bâbüssaâde ağaları unvanı verilmişti (Altındağ,1991:1). Ancak harem-i hümâyûn'un hizmet ve muhafazası işleri ile görevli harem ağalarının nüfuzu da çok büyüktü Âmirleri olan Bâbüssaâde ağası, aynı zamanda bütün Enderun ve Harem görevlilerinin âmiriydi. Hadım ağalar sarayın kadınlara ait kısmına nezaret ettiklerinden kendilerine "kızlar ağası" da denilmiştir. Aynı zamanda haremeyni'ş-şerîfeyn evkâfi denilen Mekke ve Medine vakıflarının nezareti ve bu vakfa ait dolap denilen hazinenin de âmiri olan kızlar ağasının nüfuzu, padişaha en yakın kişilerden birisi olmasından geliyordu (Ünal,2007:27-28).

1668'de Darüssaade ağası nezaretinde 313 vakıf vardı. Bu vakıfların 112'si İstanbul'da, otuz yedisi Rumeli'de, 164'ü Anadolu'daydı Nezaretinde bulunan vakıflarda Darüssaade ağasının nezaret hakkı olarak belirli gelirleri vardı. Darüssaade ağaları tarafından idare edilen Haremeyn evkafı 1834'ten itibaren onlardan alınarak Haremeyn-i şeriffeyn evkafı nazırlığı unvanı üzerlerinde kalmak üzere müstakil olarak Hazine- i Haremeyn Müdürlüğü kurulmuş ve Darüssaade ağasına nezaret hakkı olarak aylık 20.000 kuruş tahsis edilmiştir. Darüssaade ağasının hazinedar-1 şehriyarinin ve musahiblerin Ahırkapı'da konakları ve etrafında ahırları olduğu da bilinmektedir. Uhdelerinde haslar, mukataalar bulunan Darüssaade ağalarına padişah tarafından İsmail Geçidi gibi çok önemli mevkiler ve köyler temlik edilmiş, Ravza -i Mutahhara'da feraşet hizmetleri onlara tahsis edilmişti. Birçoğu oldukça zenginleşen Darüssaade ağaları cami, mescid, tekke, medrese, mektep gibi çok sayıda hayır müessesesi tesis ederek bu konuda vakfiyeler düzenlemişlerdir (Altındağ,1991:2-3).

\section{KAPI AĞASI HADIM MAHMÛD AĞA CAMI}

Bütün büyük devletlerde olduğu gibi Osmanlı Devleti'nin da gücünü ordularıyla olduğu kadar mimarlığıyla da dile getirmesi doğaldı (Kuban,1988:582) Osmanlı Devleti'nin Türk mimarlığının tabiî devamını temin ederek ona şerefli bir başkalaşma yaşatmıştır. XIV. yüzyılda Bursa ve İznik’te başlayan Osmanlı mimarlığının ilk eserleri XV. Yüzyılın sonlarına kadar hayli yol almış XVI yüzyılda Mimar Sinan gibi değerli bir üstadın,53 sene süren şerefliğine mazhar olan devlet mimarî teşkilatı, Türk mimarlığ dünyada saygı ve hayranlık uyandıran eserler bırakmıştır (Anadol,2007:313).

Mimar Sinan'ın camilerinin, mimarlık tarihindeki büyük yerini oluşturan temel faktörlerden biri de uyguladığı üstün teknolojidir (Kuban,1988:582). Mimar Sinan'ın yapılarına ilişkin en eski kaynaklar olan Tezkiret ûl-Bünyan'da 81, Tezkiret ül-Ebniye'de 84,Tuhfet ül-Mi'marinde 103 Camiye yer verildiğini, üç tezkerede adı geçen camilerin toplam sayısının 107 olduğunu ve bunlardan 79'unun üç, üçünün iki, 25'inin de tek tezkerede yer aldığını görürüz. Bu sayısal derlemenin ortaya çıkardığı gerçek şudur. Tezkiret ûl-Bünyan ve Tezkiret ül-Ebniye arasında uyum vardır ve iki kaynak arasındaki üç sayılık küçük fark iki caminin birinci tezkere kaleme alındığında henüz tasarlanmamış, birinin de hata sonucu listeye alınmış olmasıyla açıklanabilir (Kuran,1979:81).

Aptullah Kuran Mimar Sinan'ın ana kaynaklarda sözü edilen camilerini incelerken bu eserlerden bazılarının ayakta olsalar bile zaman içerisinde değişimlere uğrayarak 16. yüzyıl 
mimarî görünümlerini büyük ölçüde ya da tümüyle kaybetmiş olarak günümüze ulaşan 15 camiden birisinin Mahmud ağa cami olduğunu belirtir (Kuran,1988:184).

Osmanlı şehir ve toplum hayatını derinden etkilemiş olan vakıf sistemi birçok araştırmaya konu olmuştur. Çalışmamıza konu olan Mahmud Ağa cami yukarıda bahsettiğimiz Bâbüssaâde (Kapı) Ağası Nezâreti’nce yönetilmiştir (Ural,2011:12).

Ahırkapı Fenerlikapı Sokak'ta yer alan Mahmûd Ağa Cami, Kanuni Sultan Süleyman'ın Babüssaade ağası (Süreyya,1996:311). Olan Mahmut Ağa tarafindan H.961 (M.1553) yılında yaptırılmıştır. Eser "Kapı Ăgası Cami” ve "Ă̆a Cami” veya "Kapı Ăgası Hadım Mahmud Ăga Cami” diye de anılmaktatır (Ural,2011:12). Caminin yapıldığı yıllarda aşağısında medresesi bitişiğinde mektep ve çeşmesi vardır (Galitekin,2001:92). Cami Tezkiretül-ebniyede Mimar Sinan'ın yapıtları arasında kaydedilmektedir (Çelebi,2003:205).

Hadîkatü'l-Cevâmi adlı kitapta caminin kapı kemerinin üzerinde Farsça aşağıdaki dörtlüğün yazıldığı kaydedilmektedir. Bu kitabeler günümüze ulaşmıştır Dörtlük şeklindeki kitabenin son dizesinde ebcet hesabıyla binanın bitiş tarihi verilmiştir (Galitekin, 2001:81).

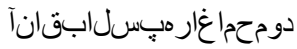
Mahmûd Ağa-yısipihr-i ikbâl ân

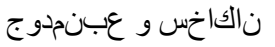
Kân-i sehâ -ümenbâ-ı cûd

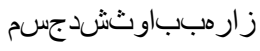
Ez beher-i sevâbmescideş
دشخير ات( انبريخدومحم)
Şüdtârih-i (binâhayr-i Mahmûd)
H.961 (M.1553)

Mahmûd Ağan'ın bahtı ki cömertlik ve sahavet madenidir sevap için mescidi bina oldu (bina hayr-1 Mahmûd ) H.961,M.1553

Reşat Ekrem Koçu İstanbul camileri kitabında eserin mimari özellikleri ile ilgili şu bilgileri aktarır;

"Cami üç büyük tonos ve sarnıç üzerine inşa edilmiştir. Camiye üç taraflı bir piramit taş merdiven ile çıkllır, son cemaat yeri yoktur, giriş kapısında evvelâ dar bir koridora girilir, bunun ortasında ve solunda ikinci bir küçük koridor, bu koridorun iki yanında kafeslerle bölünmüş iki küçük oda, gerisinde de asıl ibadet yeri bulunur. Minareye, aşağıdaki kafesli odadan çıkılır. Kadınlar mahfili yoktur; kadınlar, alttaki kafesli odaların üstüne isabet eden ve medreseden camiye ilhak edilmiş olan iki oda da ve cami içindeki maksurelerde namaz kllarlar. Sağ ve sol duvarlarda üçerden altı ve mihrap duvarında iki ki, cem'an sekiz yüksek pencere ile aydınlatılmış yukarıdaki iki odanın ortasında küçük bir balkon şeklinde bir müezzin mahfili, bir ahşap minberi, ahşap bir vaaz kürsüsü bulunmaktadır. Camin haziresi, taş merdivenli cephesi önünde, yol kenarında dar ve uzun bir sed üstündedir. Minare arka tarafta ve tuğla yapı, kurşun örtülü ahşap külahlıdır." Diyerek bahsediyor (Koçu, Tarihsiz :23). Evliya Çelebi de seyahatnamesinde cami ile ilgili kısa tarifinde dört köşe, balıksırtı tahta kubbesi ve bir şerefeli ölçülü taş minaresi bulunmaktadır der (Kahraman, 2013:239).

Mahmûd Ağa cami de 1865 Hoca paşa yangınından sonra yenilenmiş bir yapıdır. Günümüzde caminin bodrum duvarları düzgün kesme taşla örülü, beden duvarları sıvalıdır. İç duvarlarında ve tavanında süsleme bulunmayan camin minaresi yuvarlak gövdeli, sivri kurşun külâhlı, üstü kiremit döşeli ahşap çatılıdır. Ne var ki, şimdi sakıflı olmasına rağmen yapının kalın taş duvarları ve kareye yakın planı caminin eskiden kârgir kubbeyle örtülü olduğu izlenimini verir (Kuran, 1988:185). 
Çeşitli tadilatlar geçiren Sütlüce Mahmûd Ağa Cami, 1965 yılında önemli bir tamirat daha geçirerek büyütülmüş, caminin iç kısmında daha geniş bir son cemaat mahalli ilave edilmiştir. $600 \mathrm{~m}^{2}$ toplam arsa üzerine inşa edilen cami $400 \mathrm{~m}^{2}$ alan üzerine kuruludur. Tuğladan yapılmış tek şerefeli bir minaresi vardır( http:// www. beyoglumuftulugu. gov.tr/cami/mahmut-aga-cami/124/) Caminin banisi Mahmûd Ağa hazirede metfundur (Ural,2011:12).

\section{MAHMÛD AĞA CAMI'NİN HİCRİ 1020(M.1611) YILINA AİT VAKIF GELIR VE GIDERLERI}

Bâbüssaâde Ağası Osman Ağa'nın nezaretinde olan ve İstanbul'da bulunan sabık Bâbüssaâde Ağası Mahmûd Ağa'nın yaptırdığı cami-i şerife ait vakfın 1020 senesi Muharreminin başından zilhiccesinin sonuna kadar gelir ve giderlerini içeren defteridir.

Vakfin önceki yıldan kalan ve 1020 yılında bulunan Kar miktarı 244787

Önceki yıldan kalan 172835

Şahıslardan alacaklar 117700

Vakıfta hali hazırda bulunan55135

Tahsil olunan para 16410

- Ahmed Muslihiddin den ev kirası olarak 01.Ş.1018 ila 29.Z.1019 (ŞabanRamazan-Şevval-Zilkade-Zilhicce) tarihleri arasına ait 5 aylık tahsilât 2040

- Kapıcı Osman Beyden ev kirası olarak 01.C.1018 ila 29.S.1019 (CemaziyelahirRecep-Şaban-Ramazan-Şevval-Zilkade-Zilhicce-Muharrem-Safer) tarihleri arasına ait 9 aylık tahsilat 1080

- Çerkez Hasan Bey'den ev kirası olarak 01.N.1019 ila 29.Z.1019 (RamazanŞevval-Zilkade- Zilhicce) tarihleri arasına ait 4 aylık tahsilât 2040

- Hüsrev Ağa'dan ev kirası olarak 01.M.1016 ila 29.Z.1019 tarihleri arasına ait 12 aylık tahsilât 5760

- Kapıcı İbrahim Bey'den ev kirası olarak 01.Ş.1018 ila 29.Z.1019 (ŞabanRamazan- Şevval -Zilkade -Zilhicce ) senelerine ait 5 aylık tahsilât 2040

- Bazı kimselerden cami-i şerif yanındaki odaların kirası olarak 1018 yılına ait tahsilât 2310

- Mustafa Bey'den Ayasofya-i Kebir yanındaki evin 01.N.1019 ila 29.Z.1019 (Ramazan -Şevval -Zilkade -Zilhicce ) tarihleri arası 4 aylık kirası için tahsilât 360

- Yunus Hoca'dan Ayasofya yanındaki ev için 01.Ş.1019 ila 29.Z.1019(Şaban Ramazan-Şevval -Zilkade-Zilhicce) tarihleri arası 5 aylık kira tahsilâtı 450

- Ayasofya-i Kebir çarşısındaki dükkânların 1019 yılına ait kira tahsilâtı 1140

- Kadırga limanı yanındaki evin Ömer Bey el-Cündiden tahsil edilen 1019 yılı kira bedeli 120

- Hirak ve Mayka yahudilerden 1019 yılı için ev kirası 1070

- Freyde yahudiden 1019 senesi için ev kirası 420

- Andreya zimmîden Galata haricindeki dükkânın 1019 yılı kirası 340

Camiye Ait Vakfın 1.M.1020 ila 29.Z.1020 Tarihleri Arasındaki Çeşitli Malların Karşılığını da İçeren Gelirler: 72152

- Cafer Ağa ve Ümmühan hatun uhdelerinde bulunan Cami-i şerif yanındaki 1 büyük evin kira bedeli, günlük 16, senelik 5760 
- Hane-i Kebire bitişik ve Hüsrev ağanın sorumluluğunda bulunan 1ev kirası günlük 4, senelik 1140 baki (artan)

- Cami-i şerif mahallesinde Hacı Ali sorumluluğunda 1 evin kira bedeli günlük 5 yıllık 1800

- Cami-i şerif mahallesinde Mustafa Habbâz sorumluluğundaki odalardan 1 bir dükkân kira bedeli. 720

- Cami-i şerif mahallesindeki 21 odanın kira bedeli, günlük 21, senelik 7560, makbuz 5850, bakıyye 1710

- Cami-i şerif mahallesindeki 3 odanın kira bedeli, günlük 6, yıllık 2160, makbuz 1290, bakıyye 870

- Masthane-i amire yakınında ve Ahmed Muslihiddin sorumluluğunda bulunan 1 hanenin kira bedeli günlük 4 yıllık 1440.

- Masthane-i Amire yakınında ve Ali Mandıra sorumluluğunda bulunan 1 hanenin kira bedeli. Günlük 4, yıllık 1440

- Masthane-i amire yakınında ve Bevvab-1 Sultani Osman Bey sorumluluğunda bulunan 1 hanenin kira bedeli, günlük 4, yıllık 1440 bakıyye

- Masthane-i amire yakınında ve Çerkez Hasan Bey sorumluluğunda 1 hanenin kira bedeli. Günlük 2 yıllık 720, makbuz 480, bakıyye 240

- Ayasofya-i kebir yakınındaki 2 odanın kira bedeli, günlük 6, yıllık 2160, makbuz 1980, bakıyye 180

- Ayasofya-i kebir bitişiğinde 1 Pazarcı dükkânının kira bedeli, günlük 4, sene 1440, makbuz 1200 bakıyye 240

- Ayasofya-i kebir bitişiğinde 3 dükkânın bedeli, günlük 8 senelik 2880, makbuz 1860 , bakiyye 1020

- Galatada Mahmud Efendi sorumluluğunda 1 odanın kira bedeli, günlük 3, yıllık 1080, bakiyye

- Kadırga limanı yakınında ve Ömer Bey el-Cündi sorumluluğunda bulunan 1 hanenin mezkûr tarihli kira bedeli. Günlük 2, yıllık 720, makbuz 600, bakıyye 120

- Gedik Ahmet Paşa mahallesinde Ahmed çavuş sorumluluğundaki 1 dükkân ve hanenin kirası günlük 8, senelik 2880, makbuz 2160, bakıyye 720

- Hocapaşa mahallesinde İsak Yahudi sorumluluğundaki bulunan 1 odanın kira bedeli, günlük 6 , yandığından dolayı iptal edildi.

- Hocapaşa mahallesinde İsrail Yahudi uhdesinde bulunan1 evin kira bedeli, günlük 8 , yandığından dolayı iptal edildi

- Hocapaşa mahallesi yakınlarındaki bulunan ve Hirah, Mayka ve Kasbar Yahudilerin sorumluluklarında bulunan 6 hanenin kira bedeli, aylık 800, senelik 9600, makbuz 8610, bakıyye 990

- Hocapaşa mahallesinde Harun Yahudi uhdesinde bulunan levin kira bedeli, günlük 14, senelik 5040

- Hobyar mahallesinde Freyde Yahudi uhdesinde bulunan 1 evin kira bedeli, günlük 14, senelik 5040, makbuz 4620, bakıyye 420 
- Baba Yahudi mahallesinde Hayyım ve Hobe Yahudi Vadden Yahudi sorumluluklarında bulunan 1evin kira bedeli, günlük 16, yıllık 5760,

- Baba Yahudi mahallesinde, Sultan Mehmed Han'ın validesinin yaptırdığı cami binasından 1 evin kira bedeli, günlük 9, senelik 3240, bakıyye

- Çelebi zade mahallesinde Hayyım ve Abraham Yahudiler sorumluluğunda bulunan 1 evin kira bedeli, günlük 12, yandığından dolayı iptal edildi

- Vefazade meydanı yanında ve David oğlu Yasef Yahudi sorumluluğunda bulunan 1 evin kira bedeli, günlük 7 , senelik 2520

- Galata haricinde bulunan dükkânın kira bedeli, aylık 70, senelik 840, makbuz 700, bak1yye 140

- Galata'da bulunan 1 firının kira bedeli, aylık 6, senelik 72

- Vakıf sermayesine ait malların kullanımından doğan kar 1 Muharrem 1020 ile 29 Zilhicce 1020 tarihleri aras1, senelik 400 (TS.MA.d .03620-0005-00-003).

\section{Çeşitli Gelirler 4000}

- Vefat eden Yunus Müezzine ait olan hanenin Huri Hatun mülküne verilmesinden: bedel 3000

- Gedik Ahmet Paşa mahallesinde bulunan vakıf evinin Ahmed Çavuş mülküne verilmesinden, bedel 1000

\section{Çeşitli Masraflar 75322}

- Evkaf Müfettişi Mevlana Ali Efendi’nin senedi gereği önceki yıllardan kalan hariç 1 muharrem sene 1020 ila 29 Zilhicce sene 1020 arası vazifelilere ödenen.

31 nefer, günlük 60, yıllık 21600

\section{Cami-i Şerif Evkafı Zabitanı ve Ümmihan Hatun Vazifesi}

- Bâbüssaâde Ağası Çağal? Ağa, günlük 3

- Mütevelli Cafer Ağaya, günlük 5

- Vakıf kâtibi Mehmed'e günlük 3

- Vakfın cabisine (gelirlerini toplayan görevli), günlük 6

- Meremmeti (Tamirci) günlük 2

- Ümmihan hatun vakfedenin şartı gereği günlük 5

- $\quad$ Tümü 6 nefer, günlük 19, senelik 6840

\section{Cami-i Şerif Hademelerine}

- Hatib için günlük 7

- İmam için günlük 5

- $\quad$ Üç nefer müezzin için günlük 6

- Sala müezzinleri için günlük 2

- $\quad$ Baş muhassıl için günlük 2 verilen günlük 1. Bakıyye günlük 1

- Musaddık günlük 1

- 6 nefer hafız günlük 9 ,

- $\quad$ Naathân (peygamber için övücü şiirler okuyan kişi) için 3

- 2 cami hademesi için günlük 4

- Yasin okuyan için günlük 2

- Tebareke okuyan için günlük 1

- Amme suresi okuyan günlük 1 
- Ayetel Kürsi okuyan günlük 1

- Lafzatullah okuyanları günlük 1

- Cami temizlikçisi ve su taşıyan için günlük 2

- Tümü 23 nefer, günlük 34, senelik 12240

- Mekteb çalışanları, öğretmen günlük 5, halife günlük 2, toplam 2 nefer günlük 7, y1llik 2520

- Sabah vakti Cüz okuyan 15 kişiye verilen günlük 3

- Akşam vakti Cüz okuyan 15 kişiye verilen günlük 3

Tamir İle Birlikte Masraflar 53722

\section{Cami-i Şerif Masrafı 5453}

- Pamuk mumu fiyatı 360

- Zeytinyağı fiyatı 90 litre, birim fiyat 17 , bedel 1530

- Berat gecelerinde sabahları yakmak için balmumu toplam 12 adet birim fiyatı 7 tutar 84

- Berat geceleri için Süzme bal mumu 2 adet, birim fiyat 100, bedel 200

- Şamdanlar 120

- Cami-i şerif mühimmatı olarak minare kandilleri toplam 6 adet, birim fiyatı 7, bedel 42

- Cami-i şerifin Enderun kısmı için frengi kandiller toplam 10 adet, birim fiyat 3, bedel 30

- Minare dâhil olmak üzere cami-i şerifin bazı kandillerinin toplamı 26

- Ramazan gecelerinde minarelerdeki kandilleri yakmak İçin bedel, 150

- Ramazan gecelerinde tespih çekenlere verilecek ücret, 180

- Cami-i şerif süpürgeleri 41

- Cami-i şerif helva hanesi için ve cami için kova adet 1 bedel, 90

- Cami-i şerifte halı serenlere verilen ücret 30

- Cami-i şerif kafeslerinin tamiratı adet 795

- Cami-i şerif süprüntülerini taşımak ve atma bedeli 11

- Şamdan bedeli 10

- Cami çatı direkleri toplam 20 adet, birim fiyatı 9 hamaliye 4 bedel 184

- Cami-i şerif için Saz hasir adet 2, bedel 80

- Cami diş yüzey tamiri ücreti 40

- Vakıf mallarını tahsil edenlerin ücreti 850

- Vâkıf için gerekli saç ve bakır bedel 600

Tamir Bedeli 48269

- Cami-i şerif imamına ait evin tamiratı 380

- Müezzin Atâ’ya ait odanın tamiratı 220

- Şaban müezzine ait odanın çatı tamiratı 190

- Ahmed Çelebi'ye ait odanın tamiratı 150 
- Freyde Yahudiye ait evin tamirat 620

- Ahmed Muslihiddine ait evin tamirati 120

- Gedik Ahmed Paşa mahallesindeki evin tamiratı 546

- Sibyan mektebinde bulunan işlemelere ait tamirat 43

- Eski vakıf müfettişi Mevlana Ali Efendinin gözetimine dayanarak, Çelebizade mahallesinde bulunan Refika bint-i İsak'ın evinin yanmış olmasından dolayı yeniden inşa edilmesi, 46000

- Kalan meblağ 190665

- Kar Getiren ve Getirmeyen Mallardan Kişiler Ellerindeki Alacaklar 118076

- $\quad$ Eski mütevelli Hasan Efendi elindeki mallar 76600

- Gelir/faiz getiren mal, altında Petro zimmîde olan dört bin akçe mal-1 merbuh olduğuna şerh verildi.

- Üsküdar kazasına tabi Kadı karyesinde sakin Petro zimmîde olan ev kirası 01 Muharrem 1020 ila 29 Zilhicce sene 1020

- Gelir Getirmeyen Alacaklar 22600

- Nahlbend mahallesinde Mahmud Efendi'den ev kirası olarak alınacak meblağ 01 Muharrem sene 1008 ila 29 Zilhicce sene 1012 tarihleri arası, 4770

- Mehmed Bey el-Cündi'den alınacak ev kirası 01 Muharrem 1010 ila 30 Cemaziyelevvel sene 1012, 4350

- Kapıcı Bayram Bey'in hanımı Mümine Hatun'dan alınacak olan Ayasofya-yı Kebir çarşısında dükkân kirası 1010 senesi başından 1012 senesi Cemaziyelevvel ayı sonuna kadar. 3480

- Hatuniye mahallesinde sakin olan Dergâh-1 Ali çavuşlarından İbrahim Çavuş'ta olan vakıf akçesi, 01.Ra sene 1007 ila 30 Ca sene 1012, bedel 10000

- Mezkûr (adı geçen) İbrahim Çavuş Engürüs seferinde serdar tarafindan öldürüldüğünden mallarına miri adına el konulup, İstanbul'da vakf-1 mezbura rehin eylediği evi dahi gelir getirmediğinden tahsili mümkün olmadığına şerh verildi.

- Sonraki Mütevelli Zevvakin Cafer Ağa Zamanındaki Alacaklar. 41476

- Nahlbend mahallesinde bulunan evin 01.B.1012 ila 29.Z.1020 seneleri arası kirası için Kâtip Mehmed Efendiden alınacak meblağ, 9270

- Masthane yakınındaki evin 01.L.1015 ila 29.Z.1018 arasındaki kirası için Muhammed Bey el-Cündi'den alınacak meblağ 2250

- Kapıcı Bayram Bey'in hanımı Mümine Hatun'dan alınacak olan Ayasofya-yı Kebir çarşısında dükkân kirası 01.C. 1012 senesi ila 29.Z.1020 yılları arası. 3720

- Bazı kimselere kiralanan oda ve dükkânların 1020 senesine ait kira bedelleri 720

- Bazı kimselere kiralanan Ayasofya çarşısı yanındaki hane ve dükkânların ve Galata'daki dükkânın bedelleri 1186

- Kapıcı Osman Bey’den alınacak hane kirası 01,Za.1019 ila 29 Z. 1020, 2640

- İbrahim Beyden alınacak ev kirası 1020 senesi için 870

- Çerkez Hasan Bey’den alınacak ev kirası 1020 senesi için 240 
- Huri Hatun'dan alınacak Ayasofya-i Kebir çarşısı yanındaki oda kirası, 1020 senesi için 180

- Ayasofya-i kebir çarşısı yanındaki Bazari? Kirası, 1020 senesi için 240

- Adı geçenlerden alınacak Ayasofya-i Kebir yanındaki dükkânların kirası, 1020 senesi için 1020, (...) 360, Bali Hayyât 240, Verko 420 için 120

- Ömer Bey el-Cündi'den alınacak Kadırga limanı yanındaki ev kirası 1020 senesi

- Hüsrev Ağa'dan alınacak cami-i şerif yanındaki ev kirası, 1020 senesi için 1440

- Ahmed Çavuş’tan alınacak Gedik Ahmet Paşa mahallesinde bulunan ev kirası 1020 senesi için, 720

- Adı geçenlerden alınacak Hoca Paşa mahallesinde bulunan evin kirası, 990, Hirah 360, Kassab, 630

- 1020 senesi için Freyde Yahudi'den alınacak ev kirası 520

- Sultan Mehmed Han'ın validesi tarafından yaptırılın cami-i şerife dahil edilmiş olan evin kira geliri, 01. Ş 1017 ila 29 Zilhicce 1020 bedel 1170

- Cami-i şerif bünyesinde bulunan odalar için bazı kimselerden alınacak kira bedeli, 1020 senesi için, 1710

- Meydan ve çayır yanında bulunan evin David oğlu Yasef’ten alınacak kira bedeli, 1020 senesi, 2520

- Galata haricinde bulunan dükkânın kira bedeli, sene 1020 için, 140

Vakıf hazinesinde bulunan ve yedek olarak ayrılmış olan meblağdan gelecek senenin paras1 51589

1-10 Muharrem sene 1021(TS.MA.d .03620-0005-00-004)

\section{Sonuç}

Osmanlı Devletinin yükselme dönemi siyasi, askeri, ekonomik, kültürel pek çok alana damga vurduğu gibi mimari alanda da önemli eserlerin yapıldığ 1 bir dönem olmuştur. Çalışmamıza konu olan Cami Osmanlı klasik döneminde sarayda önemli bir konum olan Babüssaade Ağası Mahmûd Ağa tarafından Osmanlının Koca lakabıyla bilinen Mimar Sinan'a yaptırılmıştır. Fakat Cami Sinan'ın diğer eserleri yanında hacim bakımından küçük ve mimari özellikler nedeniyle çok bariz özelliklere sahip olmaması nedeniyle yapıldığı dönem eseri yaptıranın görevi ve mimarının büyüklügü kadar tanınmış bir eser değildir. Başbakanlık Osmanlı arşivinde cami ile ilgili ele aldığımız bir yıllık vakıf belgeleri bulunmaktadır.

Bir seneye ait vakıf belgeleri 463 yıllık bir eserin tarihini tam olarak aydınlatmamaktadır fakat mevcut bilgilere katkı sağlamaktadır. Vakıf giderlerinde yer alan kalemlerde caminin dış yüzey, çatı, imam evi, müezzin odasının tamir masrafları verilmektedir bu bize caminin 1611senesinde küçük çaplı bir bakımdan geçirildiği bilgisini vermektedir. Yine giderler içinde yer alan Mektep çalışanları, öğretmen giderleri ile Sıbyan mektebinde bulunan işlemelere ait tamirat masrafının bulunması Ayvansarayi Hüseyin Efendi'nin Hadikatü'l Cevâmi eserinde bahsedilen Caminin yapıldığı yıllarda bitişiğinde mektebi bulunmaktadır. 
Vakfın önemli gelirleri arsında Galata, Ayasofya, Hocapaşa Mahallesi, Üsküdar, Çelebizade, Gedik Ahmet Paşa, Vefazade, Nahlbent Mahallesi, Çelebizade mahallesi, Hobyar Mahallelerinde bulunan dükkân, ev ve oda gelirleri önemli yer tutmaktadır. Kiracılarının isimlerinden anladığımız kadarıyla bu semtlerde Yahudiler bir nüfus oluşturmaktadır. Vakfın gelirleri cami görevlileri olarak zikredilen Hatip, İmam, müezzin, sala müezzinleri, hafız, Naathân, temizlikçisi toplamda sayıları yirmi üçü bulan ve yine camin mektebinde çalışan öğretmen dâhil yedi çalışanın ücretlerini karşılamaktadır. Vakıfların önemli bir yönü kendini idame ettirmesi için bir kaynak oluşturulmasıdır. Bu noktada vakıf banisi yaptırdığı cami, sıbyan mektebi ve medrese için gerekli olacak maddi kaynağ İ́stanbul'un önemli semtlerindeki ev ve dükkân gelirleri ile oluşturmuştur.

Mahmûd Ağa Cami’nin bitirildiği tarih olan 1553 yılı aynı zamanda Mimar Sinan'ın Kalfalık eseri olarak bilinen Süleymaniye Caminin 1551-1557 yapıldığı yıllarla denk gelmektedir. Bu durum Mahmûd Ağa Cami'nin Mimar Sinan’ın büyük eserleri yanında çok fazla mimari özelliğiyle ön plana çıkmamasının bir nedeni olabilir. Cami günümüze 16. Yüzyıl ve Sinan'ın Mimari özelliklerini koruyarak ulaşmamış olsa da Sinan eserleri içinde yerini alarak günümüzde ibadethane olarak hizmet vermektedir.

\section{BİBLIYOGRAFYA}

\section{A. Arşiv Belgeleri}

\section{Başbakanlık Osmanlı Arşivi (BOA)}

\section{Topkapı Sarayı Müzesi Arşivi Evrakı}

\section{BOA. TS. MA. d. Gömlek 03620}

\section{B.Kitap, Makale ve Tezler}

Altındağ Ülkü (1991), "Dârüssade”, Türkiye Diyanet Vakfi İslam Ansiklopedisi, (DİA), Türk Diyanet Vakfı Yayınları, Cilt: IX, s.32-4, Ankara.

Anadol Cemal (2007), Türk Kültürü ve Medeniyeti, Bilge Karınca Yayınları, İstanbul.

Akbulut İlhan (2007), "Vakıf Kurumu, Mahiyeti ve Tarihi Gelişimi”, Vakıflar

Dergisi, Sayı XXX,.ss.61-72, Ankara.

Bahaeddin, Yediyıldız (2012), “Vakıf” Maddesi, Milli Eğitim Bakanlığı, (MEB) İslam Ansiklopedisi, Cilt.XIII, ss.479-486, Ankara.

Bayartan Mehmet (2008), “ Osmanlı Şehirlerinde Vakıflar ve Vakıf Sisteminin Şehre Kattığı Değerler”, Osmanlı Bilimi Araştırmaları, İstanbul Üniversitesi Yayınları, Sayı X1,ss.155-178,İstanbul.

Bayır Önder (2012), “Arşiv Belgelerine Göre Balkanlardaki Osmanlı Vakıfları.” Balkanlarda Osmanlı Vakıfları ve Eserleri Uluslararası Sempozyumu, Vakıflar Genel Müdürlüğü Yayınları, ss.325-339,Ankara.

Bekçi İbrahim, Apalı Ali, Karataş Nilüfer (2015), "Evkaf-Haremeyn Muhasebeciliğinde Damad İbrahim Paşa Evkafi", Muhasebe ve Denetime Bakış, Yıl 15 Say1,46,ss11-33, Ankara.

Çelebi Sâi Mustafa (2003), Yapılar Kitabı, Tezkiretü'l - Bünyan ve Tezkiretü'l Ebniye, Koç Kültür Sanat Tanıtım, İstanbul. 
Galitekin Ahmet Nezih (2001), Hadikatü'l Cevâmi (İstanbul Câmileri ve Diğer Dîn̂̂ Sivil Mimârî Yapılar, İşaret Yayınları, İstanbul.

Kahraman Seyit Ali; Dağlı, Yücel (2013), Günümüz Türkçesiyle Evliya Çelebi Seyahatnâmesi, C.1,Yapı Kredi Yayınları, İstanbul.

Koçu, Reşat Ekrem (Tarihsiz), İstanbul Camileri, Tan Matbaası, Cilt.I., İstanbul.

Köprülü, Fuat, (1942), "Vakıf Müessesesinin Hukuki Mahiyeti ve Tarihi Tekamülü”, Vakıflar Dergisi, Sayı.1 ,ss1-36, Ankara.

Korkusuz Refik; ERGÜL, Ömer, (2009),"Hukuksal Boyutları ile Eski ve Yeni Vakıflar”, Dicle Üniversitesi Hukuk Fakültesi Dergisi, S. 16, ss. 69-138, Diyarbakır.

Kuban, Doğan,(1998), “Sinan’ın Dünya Mimarisindeki Yeri”, (Ed. Sadi Bayram), Mimarbaşı Koca Sinan. Yaşadığı Çă̆ ve Eserleri, Başbakanlık Vakıflar Genel Müdürlüğü Yayınları, Ankara.

Kuran, Aptullah,(1988), “Mimar Sinan'ın Camileri”, (Ed. Sadi Bayram), Mimarbaşı Koca Sinan. Yaşadığ Çăg ve Eserleri, Başbakanlık Vakıflar Genel Müdürlüğü Yayınları, Ankara.

Kuran, Aptullah,(1979), “Mimar Sinan’ın Bilinmeyen ve Kaybolan Camileri”,

Beşeri Bilimler — Humanities, Boğaziçi Üniversitesi Dergisi, Sayı. 7.ss.8194,İstanbul.

Mehmet, Süreyya, (1996), Sicill-i Osmanî, Tarih Vakfı Yurt Yayınları, Cilt. 4. İstanbul.

Kaya, Miyase Koyuncu, (2014), “Vakıf Kurucusu Olarak Osmanlı Esnafı (18. Yüzyıl İstanbul Örneği)”, Vakıflar Dergisi, Aralık, Sayı 42,ss.35-55.

Turan, Ahmet Nezihi, (1999), “Mahremiyetin Muhafizları Darüssaade Ağaları", Osmanlı Araştırmaları, Enderun Kitapevi, ss.123-148.İstanbul

Ural, Başak Oğuz, (2011), İstanbul'un 100 Mimar Sinan Eseri, İstanbul Büyükşehir Belediyesi Yayınları, İstanbul.

Ünal, Mehmet Ali ,(1997), Osmanlı Müesseseleri Tarihi, Kardelen Kitapevi, Isparta.

Ünal, Mehmet Ali ,(1999), Osmanlı Devri Üzerine Makaleler-Araştırmalar, Kardelen Kitapevi, Isparta.

\section{Internet Kaynakları}

http://www.beyoglumuftulugu.gov.tr/cami/mahmut-aga-cami/124/ 